\title{
The Roles of Dive Centers in Conserving Coral Reefs to Support Tourism Industry in Gili Trawangan
}

\author{
I Gusti Ngurah Paulus Widya Eka Saputra \\ Universitas Gadjah Mada \\ Email: paulwekalombok@gmail.com
}

\begin{abstract}
Gili Trawangan is a popular tourism destination among scuba divers and snorkelers. It is renowned for its diverse coral reefs and marine life. However, the rapid growth of the tourism industry has a degrading impact on the condition of coral reefs. It is recorded that 25 dive centres are operating on the island. As one of the primary tourism stakeholders, the dive centre has a vital role in conserving coral reefs to support the tourism industry, to protect coral reefs as a natural resource and tourism attraction. This research has two objectives - identifying the roles of the dive centres in coral reef conservation and emphasising their focuses in supporting the tourism industry in Gili Trawangan through conservation programs. This study is qualitative research, conducted at five dive centres in Gili Trawangan. This research reveals that the five dive centres have been carrying out numerous roles in conserving coral reefs in order to support the tourism industry on the island. Moreover, each of the dive centres has various and different outcome focuses on programs they implement. Dive centres in Gili Trawangan have established a partnership with other stakeholders in order to ease implementation of their programs and to involve as many parties in conserving coral reefs.
\end{abstract}

Keywords: role, dive centre, coral reef, conservation, tourism, Gili Trawangan

\section{Background}

The outstanding biodiversity and visual attraction of coral reefs make them a pull factor for tourism (Hawkins, 2005: 374). They are the main attraction to divers and snorkelers and have a significant economic value worldwide (Gössling et al., 2008: 68). However, the expansion of coastal tourism has often killed and threatened coral reefs (Goreau, 2009: 2).

Indonesia has approximately $51,000 \mathrm{~km}^{2}$ of coral reefs, around 18 per cent of the world coral reefs are found in Indonesian waters (Burke et al., 2002: 36). Indonesia's coral reefs annual economic benefit is estimated at US\$ 1.6 billion annually (Burke et al., 2002: 8). Gili Trawangan is part of Gili Matra Marine Tourism Park along with Gili Meno and Gili Air. It is located in North Lombok Regency, West Nusa Tenggara Province. The park is one among many places in the archipelago that are known for their healthy coral reefs and abundance of marine life (Kurniawan et al., 2016: 309). Gili Trawangan is accountable for the highest number of tourist arrivals in the park (Dinas Pariwisata Kabupaten Lombok Utara, 2016b). According to Kartawijaya, up to 97 per cent visitors in Gili Trawangan are interested in scuba diving and snorkelling (Tinumbia et al., 2016: 2). Gili Trawangan is the largest island in the park and equipped with diverse coral reefs and marine life, white sandy beaches and crystal-clear water. 
With the fast growth of tourism, many local people depend on the tourism industry as the primary source of livelihood (Rianto, 2014: 6).

In recent years, the island's tourism industry has undergone rapid, uncontrolled growth which resulted in several adverse effects on reefs (Graci \& Dodds, 2010: 248). For instance, many tourism boats operating around the islands hence coral breaking from anchoring is very intensive (Bachtiar, 2000: 3). Rianto (2014) discovered that due to high dependency on the use of coastal resources; it has resulted in coral reef degradation in Gili Trawangan. The degradation is driven by fishing, pollution, waste and non-sustainable tourism practices. This adverse condition of coral reef degradation has reduced the interest of tourists for diving (Suana \& Ahyadi, 2012: 94). It is essential to remind that without protection, the quality of tourism itself will deteriorate (Edgell, 1990: 80).

If the degradation of coral reefs keeps on going, the tourism industry in Gili Trawangan will be in danger. It will threaten the economy of local communities that depend on the tourism industry (Suana \& Ahyadi, 2012: 95).

The diving industry has been recognised for its responsibility and interest in conservation (Townsend, 2008: 139). Dive centre, as one of the primary tourism stakeholders, has the most significant level of interest and impact on the sustainability of ecosystems (Suana \& Ahyadi, 2012: 97).

There are 25 dive centres registered on the island (Dinas Pariwisata Kabupaten Lombok Utara, 2016a). In this study, the researcher aims to identify the roles of dive centres in conserving coral reefs to support the tourism industry in protecting coral reef resources as its' tourism asset and natural resource. As well as to discover the focuses of their roles in conserving coral reefs through conservation programs. The researcher focuses on five dive centres in Gili Trawangan that has different characteristics with one another-namely Blue Marlin Dive, Diversia, DSM Dive, Dream Divers and Blue Marine Dive - as the primary research objects. These five dive centres are picked to represent each category of dive operation that could be found in Gili Trawangan. For instance, Blue Marlin Dive is a long-recognized, and one of the firsts dive centres established in Gili Trawangan.
Diversia is one of the most recent established dive centres. DSM Dive is a dive centre that has three branch offices located throughout Lombok. Dream Divers is an international chained dive centre under the management of Extra Divers Worldwide. Last, Blue Marine Dive is a locally owned dive centre in Gili Trawangan. ${ }^{1}$

Figure 1. Map of Gili Trawangan

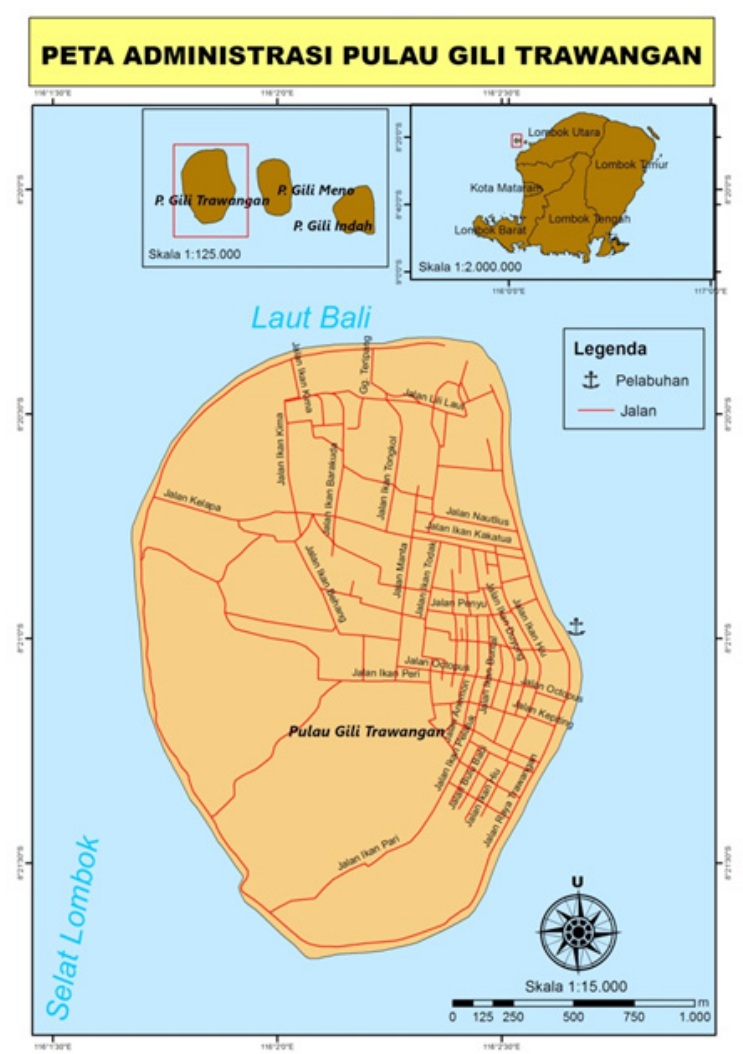

Source: Astriani, 2018

\section{Theoretical Framework}

The expansion of coastal tourism has killed coral reefs through fossil fuel emissions, land clearance and erosion, dredging, anchors, trampling and untreated sewage (Goreau, 2009: 2). The degradation of coral reefs potentially leads to dissatisfaction of tourists and poses negative impacts on tourism businesses (Wongthong \& Harvey, 2014: 139). It results in the potential loss of between 6 per cent and 18 per cent of tourism contribution to GDP in ten years (Cesar, 1996: 23). The result of the 
destruction of one $\mathrm{km}^{2}$ of the coral reef will also lead to beach erosion of one $\mathrm{km}^{2}$ coastline, beach damage, and land loss in tourist areas (Cesar, 1996: 22). If the tourism activity is not carefully planned, the degradation of the coral reefs is inevitable (Hsui and Wang, 2013: 6). Hence, tourism in and around protected areas must be designed as a conservation tool for the protection of biodiversity, ecosystem integrity and cultural heritage (World Conservation Union's World Commission on Protected Areas, 2003: 28).

Conservation is defined as planned management of a natural resource to prevent exploitation, destruction, or neglect (Ray \& Ray, 2004: $\mathrm{x}$ ). It is important to look at reefs as a means of production and source of economic income; hence coral reef conservation should be given the highest priority (Treeck \& Eisinger, 2008: 166). The economic value of coral reef tourism plays a vital role in making improved management through conservation (Hariott 2002: 12). There are two fundamentals themes to frame coral reef conservation actions; understanding coral reef ecosystems and reducing the adverse impacts of human activities. (the United States Coral Reef Task Force, 2000: 10-34).

Scuba diving industry has been characterised by its rapid growth over the past 15 years (Garrod \& Gössling, 2008: 3). According to Goodall and Stabler, the tourism industry has a major role to play in providing solutions to environmental problems (Goodall \& Stabler, 2003: 69). Moreover, for many years, the dive tourism industry is known for its role in environmental conservation (Townsend, 2008: 139). Dive centre operates and facilitates underwater tourist activities, including scuba diving and snorkelling. They provide information on environmentally harmful activities. They are in a position to actively influence diver behaviour underwater (Lindgrend et al., 2008: 115). They also have a promising role in financing coral reef conservation (Arin \& Kramer, 2002: 172). Increasing tourism interaction with the environment should lead tourism businesses to behave environmentally responsible, as they recognise the importance of maintaining quality performance (Richards \& Hall, 2000: 69). Dive centre as tourism industry could motivate environmental conservation (Swarbrooke, 1999: 51).
Figure 2 shows the framework that has been set and selected by the researcher regarding the fundamentals of coral reef conservation and roles of a dive centre in conservation. It is used by the researcher to discover dive centres' roles in conserving coral reefs to support the tourism industry in Gili Trawangan in protecting its asset.

Figure 2. The framework of Dive Centers' Roles in Conserving Coral Reefs to Support Tourism Industry

\begin{tabular}{|c|c|}
\hline $\begin{array}{l}\text { Fundamentals } \\
\text { in Coral Reef } \\
\text { Conservation }\end{array}$ & Roles of Dive Center \\
\hline \multirow{2}{*}{$\begin{array}{l}\text { Understanding } \\
\text { coral reef } \\
\text { ecosystems (the } \\
\text { United States Coral } \\
\text { Reef Task Force, } \\
\text { 2000: } 10-34 \text { ) }\end{array}$} & $\begin{array}{l}\text { Providing information } \\
\text { regarding environmentally } \\
\text { harmful activities } \\
\text { (Lindgrend et al., 2008: 115). }\end{array}$ \\
\hline & $\begin{array}{c}\text { Increasing awareness } \\
\text { of tourism interaction } \\
\text { with the environment } \\
\text { (Richards \& Hall, 2000: 69). }\end{array}$ \\
\hline \multirow{4}{*}{$\begin{array}{c}\text { Reducing the } \\
\text { adverse impacts of } \\
\text { human activities } \\
\text { (the United } \\
\text { States Coral } \\
\text { Reef Task Force, } \\
\text { 2000: } 10-34 \text { ) }\end{array}$} & $\begin{array}{c}\text { Financing coral reef } \\
\text { conservation } \\
\text { (Arin \& Kramer, 2002: 172) }\end{array}$ \\
\hline & $\begin{array}{l}\text { Managing diver behaviour } \\
\text { (Lindgrend et al., 2008: 115) }\end{array}$ \\
\hline & $\begin{array}{l}\text { Environmentally responsible } \\
\text { tourism business } \\
\text { (Richards \& Hall, 2000: 69) }\end{array}$ \\
\hline & $\begin{array}{l}\text { Motivating environmental } \\
\text { conservation } \\
\text { (Swarbrooke, 1999: 51) }\end{array}$ \\
\hline
\end{tabular}

\section{Research Method}

This research is qualitative research using a descriptive-analytical approach. As for the data collection, the researcher applied primary method through participant observation by being directly involved in dive centres activities and conducting an interview with representatives from five dive centres and governments. The researcher also applied secondary method through document and literature study to add the data richness. The data was analysed using the method by Milles and Huberman (1994: 10-12) containing three components: data reduction, data display and 
Figure 3. The framework of Dive Centers' Roles in Conserving Coral Reefs aligned with Coral Reef Conservation Programs implemented

\begin{tabular}{|c|c|c|}
\hline $\begin{array}{l}\text { Fundamentals of Coral } \\
\text { Reef Conservation }\end{array}$ & Roles of Dive Center & $\begin{array}{l}\text { Coral Reef Conservation } \\
\text { Programs }\end{array}$ \\
\hline \multirow{2}{*}{$\begin{array}{l}\text { Understanding coral reef } \\
\text { ecosystems (the United } \\
\text { States Coral Reef Task } \\
\text { Force, 2000: 10-34) }\end{array}$} & $\begin{array}{l}\text { Providing information regarding } \\
\text { environmentally harmful activities } \\
\text { (Lindgrend et al., 2008: 115). }\end{array}$ & $\begin{array}{l}\text { 1. Local staff training } \\
\text { 2. Education programs }\end{array}$ \\
\hline & $\begin{array}{l}\text { Increasing awareness of tourism } \\
\text { interaction with the environment } \\
\text { (Richards \& Hall, 2000: 69) }\end{array}$ & 3. Conservation event \\
\hline \multirow{4}{*}{$\begin{array}{l}\text { Reducing the adverse } \\
\text { impacts of human } \\
\text { activities (the United } \\
\text { States Coral Reef Task } \\
\text { Force, 2000: 10-34) }\end{array}$} & $\begin{array}{l}\text { Financing coral reef conservation } \\
\text { (Arin \& Kramer, 2002: 172) }\end{array}$ & $\begin{array}{l}\text { 4. Gili EcoTrust (GET) donation } \\
\text { 5. Biorock project }\end{array}$ \\
\hline & $\begin{array}{l}\text { Managing diver behaviour } \\
\text { (Lindgrend et al., 2008: 115) }\end{array}$ & $\begin{array}{l}\text { 6. Managing diver behaviour } \\
\text { through PADI/SSI guideline }\end{array}$ \\
\hline & $\begin{array}{l}\text { Environmentally responsible } \\
\text { tourism business } \\
\text { (Richards \& Hall, 2000: 69) }\end{array}$ & $\begin{array}{l}\text { 7. No anchoring } \\
\text { 8. Limiting the number of } \\
\text { divers in the dive group }\end{array}$ \\
\hline & $\begin{array}{l}\text { Motivating environmental conservation } \\
\text { (Swarbrooke, 1999: 51) }\end{array}$ & $\begin{array}{l}\text { 9. Dive against debris } \\
\text { 10. Beach clean-up }\end{array}$ \\
\hline
\end{tabular}

conclusion. These processes are necessary to explain the implementation of conservation programs in Gili Trawangan that are aligned with their roles as well as fundamentals in coral reef conservation to support the tourism industry in Gili Trawangan as seen in Figure 3.

\section{Research Findings and Discussion}

Tourism in Gili Trawangan has grown rapidly since the 1980s, and then scuba diving was introduced in the 1990s (Rianto, 2014: 5). Among the 25 registered dive centres on the island, the researcher picked five dive centres as main objects for data collection. The researcher justifies the selection of these dive centres, as each of them has different characteristics. Blue Marlin Dive is a long-established, and one of the firsts dive centres established in Gili Trawangan. Diversia is one of the most recent established dive centres. DSM Dive is a dive centre that has three branch offices located throughout Lombok. Dream Divers is an international chained dive centre under the management of Extra Divers Worldwide. Last, Blue Marine Dive is a locally owned dive centre in Gili TrawanganThere are several non-government organisations based in Gili Trawangan such as Gili Eco Trust (GET), SATGAS (Task Force) and Gili Indah Diving Alliance (GIDA). These organisations often collaborate with dive centres on the island concerning sustainable tourism development and environmental protection in Gili Trawangan.

\subsection{Coral Reef Conservation Programs as Implementation of Dive Centers' Roles in Conserving Coral Reefs to Support Tourism Industry in Gili Trawangan}

The dive centre as one of the primary stakeholders in Gili Trawangan has an important role in the management of the ecosystem for the sustainability of tourism development in Gili Matra Marine Tourism Park (Suana \& Ahyadi, 2012: 97). The roles of dive centres could be seen through coral reef conservation programs implemented by each dive centre.

\subsubsection{Blue Marlin Dive}

Blue Marlin Dive has eight coral reef conservation programs. These include conservation event, dive against debris, bio rock project, no anchoring, managing diver behaviour, limiting the number of 
divers in dive group, Gili Eco Trust (GET) donation and beach clean-up.

\subsubsection{Conservation Event}

This is held by Blue Marlin Dive once to twice a year annually to celebrate the World Oceans Day and Earth Day. The recent conservation event hosted by the dive centre was held on June 9, 2018. The dive centre organised several conservation talks, documentary screenings and produced conservation campaigns. The main objective is to raise public awareness on the importance of coral reef and marine environment protection, as well as to provide motivation for conservation. ${ }^{2}$

\subsubsection{Dive against Debris}

Dive against debris is a scuba diving activity held by divers to clean the ocean from marine debris while diving. Blue Marine Dive holds this program once a month. The dive centre also conducts this program to celebrate Earth Day and World Oceans Day. It is scheduled every Friday between 09.00 AM and 2.00 PM. Blue Marlin Dive usually conduct dive against debris in waters in front of the dive centre. Dive instructor and dive-master, who are available lead this program. The dive centre also encourages its dive guests who wish to participate. This program aims to raise awareness of how scuba diving as tourism activity could contribute to clean the ocean from marine debris to ensure healthy reef growth and clean marine environment. ${ }^{3}$

\subsubsection{Biorock Project}

Biorock is a technology to create artificial coral reefs, by building a steel structure and putting a direct low voltage of electricity. This low voltage also promotes corals to grow faster and stronger compared to natural reefs. ${ }^{4}$ Blue Marlin Dive installs bio rock in the waterfront of the dive centre. Not many dive centres sponsored bio rock due to its expensive cost for instalment. It costs roughly around 2,000 USD to install bio rock house where it generates an electric current that is attached to the bio rock underwater. Once the bio rock house is installed at one place, it can hook up multiple bio rocks. Through bio rock project, Blue Marlin Dive represents its role in financing coral reef conservation through a program to restore coral reefs. Biorock also becomes an interesting snorkelling and dive site for tourists who are curious about reef conservation project. ${ }^{5}$

\subsubsection{No Anchoring}

No anchoring is a program implemented by Blue Marlin Dive to prevent and reduce destruction on coral reefs. When visiting dive and/or snorkelling sites, Blue Marlin Dive boats do not drop their anchor and instead use the nearby mooring buoys provided. ${ }^{6}$

\subsubsection{Managing Diver Behaviour}

Managing diver behaviour in Blue Marlin Dive is implemented by following PADI guideline course. Blue Marlin Dive ensures its dive students to have buoyancy control skill before entering the water. Buoyancy control skill must be first learned in swimming pool in order to avoid breaking on corals and to master other scuba diving skills. Blue Marlin is also involved in Project AWARE, which is a global movement for coral reef and marine environment protection program driven by divers. Managing diver behaviour aims to avoid and prevent coral breaking, to raise awareness and to motivate divers to be involved in the protection of coral reefs and marine environment. ${ }^{\text {? }}$

\subsubsection{Limiting Number of Divers}

Limiting the number of divers in the dive group is a program that aims to monitor and control diver behaviour underwater to prevent breaking on coral reefs. The fewer number of divers, the fewer impacts on reefs. Blue Marlin Dive limits its dive group to a maximum of four divers in one dive group. One to two dive instructor and/or divemaster assist one dive group. This limit of the dive group applies to the group for fun dives and dive courses. ${ }^{8}$

\subsubsection{Gili Eco Trust Donation}

Gili Eco Trust (GET) Donation is a direct financial program where dive centres implement obligatory donation for their diver guests to support coral reef conservation. Divers are obligated to pay to 50,000 IDR and is paid only once. It is a collaborative conservation program initiated and organised by Gili Eco Trust and collaboration with dive centres, and other tourism businesses in Gili Trawangan. This donation then allocated by GET to create and place buoys/moorings at dive sites, harbour area 
and snorkelling sites, to do coral reef monitoring, conservation workshops, waste recycling are funded from this GET donation. ${ }^{9}$ Blue Marlin Dive implements this collaborative coral reef conservation program to provide a direct financial contribution to support coral reef conservation on the island through obligatory donation obtained from Blue Marlin Dive's diver guests. Only diver guests are obligated to pay. However, if non-diver guests would like to contribute to donation, they are also can. ${ }^{10}$

\subsubsection{Beach Clean-up}

Beach clean-up is held every Friday in Gili Trawangan a year-round. The program is organised by Gili Eco Trust (GET) and Gili Indah Diving Association (GIDA) and supported by tourism businesses such as dive centres, hotels, restaurants and bars in Gili Trawangan. The activity is held in different places every week. It depends on which dive centres, hotels, or other businesses host the program. Blue Marlin Dive is a member of Gili Eco Trust (GET) and Gili Indah Diving Alliance (GIDA), so the dive centre gets to host the program once in a while. Beach clean-up starts at $5 \mathrm{pm}$ and goes for an hour. Before the beach clean-up starts, a representative from Gili Eco Trust held briefings regarding trash separation. After the beach clean-up, all volunteers who participate will be rewarded with free beer provided by Blue Marlin Dive. Participants of the program usually consist of tourists, local community and tourism business owners and employees. This program represents the dive centre's role in reducing adverse impacts from human activities. It helps to prevent waste from entering the ocean and harming coral reefs and provide motivation for conservation. ${ }^{11}$

\subsubsection{Diversia}

Diversia has six coral reef conservation programs, namely dive against debris, no anchoring, managing diver behaviour, limiting the number of divers, Gili Eco Trust (GET) donation and beach clean-up.

\subsubsection{Dive against Debris}

Dive against debris in Diversia does not have a fixed schedule for dive against debris. The program is more of an initiative driven program by dive instructor or divemaster who are available and would like to do it. Diversia is estimated to hold dive against debris once in every three months. Diversia also holds Dive against debris to observe Earth Day and World Oceans Day. Diversia often holds dive against debris in waters in front of the dive centre and harbour area. ${ }^{12}$

\subsubsection{No Anchoring}

Anchor dropping contributes to coral reef destruction in Gili Trawangan's past. Therefore, Diversia conducts no anchoring to prevent and to reduce further destruction on coral reefs. ${ }^{13}$

\subsubsection{Managing Diver Behaviour}

Diversia manages diver behaviour by following PADI guideline course. Diversia ensures its dive students to have buoyancy control skill other scuba diving skills by learning in a pool first before entering the ocean. Briefings before every dive are necessary to inform divers about to safety guidelines and lower impacts on reefs. ${ }^{14}$

\subsubsection{Limiting Number of Divers}

Diversia limits the number of divers to a maximum of four divers in one dive group. One to two dive instructor and/or divemaster assist one dive group. This program helps to minimise and prevent coral from breaking by divers. ${ }^{15}$

\subsubsection{Gili Eco Trust (GET) Donation}

Diversia implements this collaborative coral reef conservation program aims to provide a direct financial contribution to support coral reef conservation. The same mechanism is used to charge diver guests with 50,000 IDR donation, in which the money is allocated for conservation purposes. 16

\subsubsection{Beach Clean-up}

Since Diversia is a member of Gili Eco Trust (GET) and Gili Indah Diving Alliance (GIDA), Diversia hosts the program once in a while. Beach clean-up starts at $5 \mathrm{pm}$ and goes for an hour. It has the same mechanism in which after the beach clean-up, all volunteers who participate will be rewarded with free beer provided by the dive centre. This reward also acts as a tool to provide their motivation to involve in conservation. ${ }^{17}$

\subsubsection{DSM Dive}

DSM Dive has six coral reef conservation programs, which are dive against debris, no anchoring, 
managing diver behaviour, limiting the number of divers, Gili Eco Trust (GET) donation and beach clean-up.

\subsubsection{Dive Against Debris}

DSM Dive holds Dive against debris once to twice a year to celebrate Earth Day and the World Oceans Day. Dive instructor and/or divemaster lead dive against debris in DSM. DSM Dive held dive against debris in front of their dive centre. ${ }^{18}$

\subsubsection{No Anchoring}

Through this program, DSM represents its role in being responsible tourism business and reducing adverse impacts from human activities by not contributing to the destruction of coral reefs from anchoring. ${ }^{19}$

\subsubsection{Managing Diver Behavior}

Briefings before every dive are necessary to inform divers about do and don'ts when diving and how to be environmentally aware and responsible for one's action. DSM also introduces the Project AWARE program, a global movement for coral reef and marine environment protection driven by PADI divers. The program aims to prevent coral breaking, raise awareness and motivate involvement in protecting coral reefs and marine environment. ${ }^{20}$

\subsubsection{Limiting Number of Divers}

DSM Dive limits the number of divers to a maximum of three to four divers in one dive group. One to two dive instructor and/or divemaster assist one dive group. This limit of the dive group applies to the group for fun dives and dive courses. ${ }^{21}$

\subsubsection{Gili Eco Trust (GET) Donation}

DSM Dive implements the Gili Eco Trust (GET) Donation to provide a direct financial contribution, the same as Blue Marlin and Diversia. DSM Dive is very strict in running this program. The dive centre stated they would not take their dive guests for diving if they denied paying the donation. ${ }^{22}$

\subsubsection{Beach Clean-up}

DSM Dive is also a member of Gili Eco Trust (GET) and Gili Indah Diving Alliance (GIDA), DSM Dive gets to host the program once in a while in a certain location agreed by members and organiser. ${ }^{23}$

\subsubsection{Dream Divers}

Dream Divers has five coral reef conservation programs in total, which are all organised individually by the dive centre. The programs include; education program for students, dive against debris, and no anchoring, managing diver behaviour, limiting the number of divers in dive group.

\subsubsection{Education Program for Students}

Dream Divers conducts education program for kids once a year at the dive centre. The program is intended for students (primary, junior high and high school) in Gili Trawangan. The purpose of this program is to use education as a conservation tool for the young generation. The recent program Dream Divers was held on May 31, 2018, with a theme, With My Two Hands Project attended by primary school students of SDN 2 Gili Indah in Gili Trawangan. Dream Divers' dive instructor and divemaster led the program. Through this program, Dream Divers uses interactive way of learning, which includes movie screening about reefs and marine environment, introduction and discussion about conservation of reefs and marine environment, the workshop on making creation out waste. Dream Divers sometimes collaborates with Gili Eco Trust to provide assistance and additional information in coral reef conservation workshop. ${ }^{24}$

\subsubsection{Dive Against Debris}

Dive against debris is held once to twice a year by Dream Divers. It is held to celebrate Earth Day and World Oceans Day. The recent dive against debris conducted by Dream Divers was on April 22, 2018, when the dive centre offered the program to its dive guests for free of charge for those who participated. The dive centre wants to raise awareness on how scuba diving as tourism activity could contribute to the protection of coral reefs and marine environment. ${ }^{25}$

\subsubsection{No Anchoring}

Dream Divers stated that no anchoring program is a small yet very important effort that would have a great contribution to the conservation of coral reefs if all businesses involved in doing so. The program shows the dive centre's role in reducing adverse impacts caused by human activities. ${ }^{26}$ 


\subsubsection{Managing Diver Behavior}

Dream Divers manages diver behaviour by following SSI guideline course. The dive centre ensures its dive students to have buoyancy control skill and other scuba diving skills. Briefings before every dive are necessary to inform divers about do and don'ts when diving and how to be environmentally aware and responsible for one's action to minimise risks on the disturbing marine environment. ${ }^{27}$

\subsubsection{Limiting Number of Divers}

Dream Divers limits the number of divers to a maximum of four divers in one dive group. One to two dive instructors and/or divemasters assist one dive group. ${ }^{28}$

\subsubsection{Blue Marine Dive}

Blue Marine Dive has eight coral reef conservation programs, which consist of the education program for students, local staff training, dive against debris, bio rock project, no anchoring, managing diver behaviour, limiting the number of divers, Gili Eco Trust (GET) donation and beach clean-up.

\subsubsection{Education Program for Students}

Blue Marine Dive facilitates students to learn about coral reef conservation. Since 2014, the dive centre has established a partnership with Jakarta Intercultural School and hosts the annual program once a year for the students' field study program. The program comprises of scuba diving and coral reef conservation by using bio rock technology. Around 20-30 students from Jakarta Intercultural School participate in the seven-day program each year. Activities within the program include taking scuba diving certification, learning about bio rock technology and making own's bio rock. Blue Marine Dive collaborates with Gili Eco Trust in regards to assistance for the bio rock. By the end of the program, the group will have one bio rock placed in Gili Matra Marine Tourism Park waters as a result of their field study visit. ${ }^{29}$

\subsubsection{Local Staff Training}

Blue Marine Dive occasionally organises training program regarding coral reef and marine environment conservation for its employees. ${ }^{30}$ "It is a tool for coral reef conservation because if we want to protect the reefs, we need the local community to be onboard so then it would benefit for the long run" (Matt McAuliffe, Blue Marine Dive Shop Manager). The recent program was training for mooring buoys procurement in Gili Trawangan waters to avoid and reduce anchoring in collaboration with Gili Eco Trust (GET) and Gili Indah Diving Association (GIDA). There were 25 mooring buoys resulted from this and placed around Gili Trawangan waters. Some volunteers participated in the program, such as tourists and divemaster training. Other training programs that Blue Marine Dive is the introductory dive for its employees. A program is an educational tool, so they understand the importance to protect the reef when they see it themselves. ${ }^{31}$

\subsubsection{Dive Against Debris}

Blue Marine Dive does not have a fixed schedule for dive against debris. It is estimated that Blue Marine Dive conducts dive against once in two or three months depending on initiatives from its dive instructor and/or divemaster. Blue Marine also celebrates Earth Day and the World Oceans Day by diving debris. They encourage their diver guests to join if they wish to participate as well..$^{32}$

\subsubsection{No Anchoring}

The dive centre represents its role in behaving as a responsible tourism business and reducing adverse impacts on coral reefs caused by human activities through this program. ${ }^{33}$

\subsubsection{Managing Diver Behavior}

Blue Marine Dive manages diver behaviour by following PADI guideline course. By managing diver behaviour, Blue Marine aims to prevent coral breaking, raise awareness and motivate involvement in protecting coral reefs and marine environment. ${ }^{34}$

\subsubsection{Limiting Number of Divers}

Blue Marine Dive limits the number of divers to a maximum of four divers in one dive group. One to two dive instructors and/or divemasters and/or divemaster training assist one dive group. ${ }^{35}$

\subsubsection{Gili Eco Trust (GET) Donation}

Blue Marine Dive implements this collaborative coral reef conservation program to provide a direct financial contribution, the same as Blue Marlin, Diversia and DSM Dive. Divers are obligated to pay to 50,000 IDR. It is only paid once per diver 
as agreed by members Gili Eco Trust (GET) and Gili Indah Diving Alliance (GIDA). ${ }^{36}$

\subsubsection{Beach Clean-up}

Since Blue Marine Dive is a member of Gili Eco Trust (GET) and Gili Indah Diving Alliance (GIDA), Blue Marine hosts the program once in a while. The program routine and mechanism are the same as other dive centres. ${ }^{37}$

The research showed that the five dive centres have multiple roles in conserving coral reefs in Gili Trawangan. The list of programs and roles of each dive centre in conserving coral reefs in Gili Trawangan are shown in the figure 4 .

There are ten coral reef conservation programs implemented in Gili Trawangan. Some dive centres in Gili Trawangan have several similar programs in conserving coral reefs. The research also reveals that some dive centres run more programs than others. Blue Marlin Dive and Blue Marine Dive are ahead with a larger number of programs. Both, Blue Marlin Dive and Blue Marine Dive have eight coral reef conservation programs, while Diversia and DSM Dive have six programs. The remaining Dream Divers has the least with only five coral reef conservation programs.

Blue Marlin Dive, for example, is the only dive centre that implements conservation event and bio rock program. Moreover, Blue Marine Dive is also the only dive centre that runs local staff training for coral reef conservation in Gili Trawangan. Meanwhile, the education program for students is implemented by two dive centresDream Divers and Blue Marine Dive. The research found that all dive centres have four similar coral reef conservation programs which are dive against debris, no anchoring, managing diver behaviour and limiting the number of divers in dive group.

\subsection{Analysis of the Focuses of Dive Centers' Roles in Conserving Coral Reefs to Support Tourism Industry in Gili Trawangan}

Conservation is now evident throughout the areas visited by tourists and is generally seen to be a very positive concept where the paces of economic and social change lead to great changes in the environment (Swarbrooke, 1999: 55). It is important to support conservation in tourism destination as tourism relies on a healthy, attractive environment for its sales (Hariott, 2002: 13). Since identified that the five dive centres have various roles in conserving coral reefs in Gili Trawangan, it is important to analyse focuses of their programs in supporting the tourism industry to protect coral reef resources.

Figure 4. List of Coral Reef Conservation Programs Implemented by Dive Centers in Gili Trawangan

\begin{tabular}{|c|l|c|c|c|c|c|}
\hline \multirow{2}{*}{ No } & \multicolumn{1}{|c|}{$\begin{array}{c}\text { Coral Reef Conservation } \\
\text { Programs }\end{array}$} & \multicolumn{1}{|c|}{$\begin{array}{c}\text { List of Dive Centers } \\
\text { Dive }\end{array}$} & $\begin{array}{c}\text { Blue Marlin } \\
\text { Diversia }\end{array}$ & DSM & $\begin{array}{c}\text { Dream } \\
\text { Divers }\end{array}$ & $\begin{array}{c}\text { Blue Marine } \\
\text { Dive }\end{array}$ \\
\hline 1. & Host conservation event & V & & & V & V \\
\hline 2 & Education program for kids & & & & & V \\
\hline 3 & Local staff training & & & V & V & V \\
\hline 4 & Dive against debris & V & V & & \\
\hline 5 & Biorock project & V & & V & V & V \\
\hline 6 & No anchoring & V & V & V & V & V \\
\hline 7 & Managing diver behavior & V & V & V & V & V \\
\hline 8 & $\begin{array}{l}\text { Limiting the number of divers in } \\
\text { the dive group }\end{array}$ & V & V & V & & V \\
\hline 9 & GET (Gili Eco Trust) donation & V & V & V & & V \\
\hline 10 & Beach clean-up & $\mathbf{8}$ & $\mathbf{6}$ & $\mathbf{6}$ & $\mathbf{5}$ & $\mathbf{8}$ \\
\hline
\end{tabular}




\subsubsection{Blue Marlin Dive}

Blue Marlin Dive runs eight out of ten coral reef conservation programs in Gili Trawangan. Two programs are not implemented by Blue Marlin Dive in conserving coral reefs such as education program for kids and local staff training. Blue Marlin Dive does not run those programs because they do not suit with Blue Marlin Dive's focus in conserving coral reefs. The dive centre focuses its role on raising general public awareness and providing motivation for tourists and the public to be engaged in conserving coral reefs. Blue Marlin Dive believes dive centre as tourism business has an important role in influencing actions and behaviours of tourists who use their services, and public surrounding Blue Marlin Dive to be aware, motivated and actively involved in conserving coral reefs in order to support the tourism industry in Gili Trawangan and the sustainability of the marine ecosystem. ${ }^{38}$

Figure 5. Dive against Debris and Campaign by Blue Marlin Dive

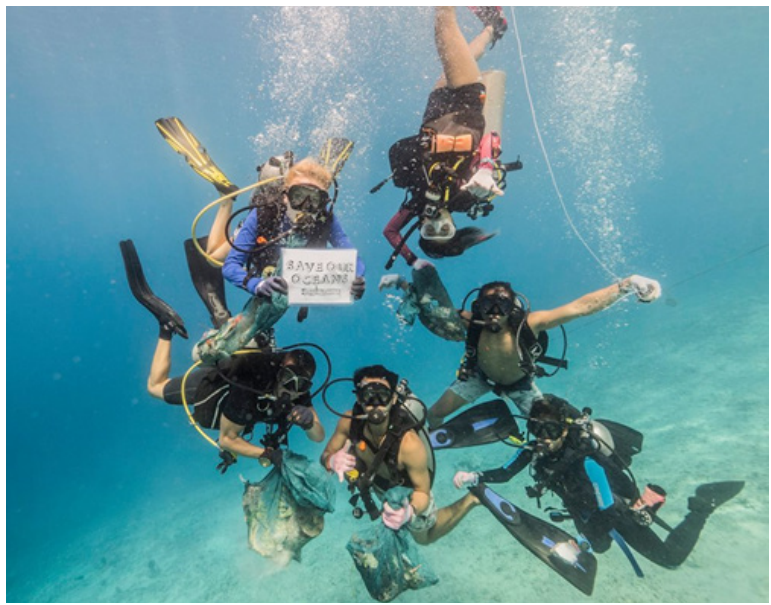

Picture: Blue Marlin Dive, 2018

\subsubsection{Diversia}

Diversia runs six out of ten coral reef conservation programs in Gili Trawangan. Diversia does not implement four programs in conserving coral reefs including conservation event, an education program for kids, local staff training and bio rock project because of the high costs. Citing an example, a program to host bio rock costs around 2000 USD for the instalment and then the bio rock needs to be monitored and checked regularly once installed.39 Diverse mentioned although the dive centre focuses on generating economic income from services they provide for tourists, the dive centre always strive to do its best in contributing for the conservation of coral reefs with the capacity that they have. ${ }^{40}$

\subsubsection{DSM Dive}

DSM Dive runs six out of ten coral reef conservation programs in Gili Trawangan. Four programs are not implemented by DSM Dive in conserving coral reefs such as conservation event, an education program for kids, local staff training and bio rock project. Since DSM Dive has three offices in three different locations - two in Lombok and one office in Gili Trawangan - the focus of running coral reef conservation programs are not a priority agenda for DSM Dive. However, DSM Dive stated that coral reef conservation should be done collaboratively with all stakeholders in order to strive for success. DSM Dive mentioned with the existence of Gili Eco Trust (GIDA), Task Force (SATGAS) and Gili Indah Diving Alliance (GIDA) in Gili Trawangan, and it helps DSM Dive and other businesses to be actively involved in coral reef conservation. The dive centre mentioned collaborative programs to be most important because everyone could take part and has a role in the conservation of coral reefs to support tourism industry for present and future use. $^{41}$

\subsubsection{Dream Divers}

Dream Divers runs five out of ten coral reef conservation programs in Gili Trawangan. Dream Divers do not implement five programs in conserving coral reefs including conservation event, local staff training, bio rock project, Gili Eco Trust (GET) donation, and beach clean-up. Dream Divers is not a member Gili Eco Trust (GET) as they do not want to charge a fee to their diver guests for the donation as it may make their guests feel uncomfortable. Although Dream Divers does not take part in the collaboration program, Dream Divers focuses its role in conserving coral reefs through the dive centre's initiatives in conserving coral reefs. It is by providing understanding about coral reef ecosystem through education program the dive centre has. The dive centre believes 
individually, and tourism businesses could strive for success and contribute to the conservation of coral reefs at the same time. ${ }^{42}$

\subsubsection{Blue Marine Dive}

Blue Marine Dive runs eight out of ten coral reef conservation programs in Gili Trawangan. Blue Marine Dive does not implement two programs in conserving coral reefs, including conservation event and bio rock project. Rather than doing conservation event, Blue Marine Dive prefers to organise small group discussions and/or workshops in more intensive ways with hands-on experience in coral reef conservation. The dive centre focuses on the educational aspect where Blue Marine Dive sees education as an important tool for conservation, as it provides understanding about the coral reef ecosystem and information about environmentally harmful activities. ${ }^{43}$

Figure 6 shows the summary of dive centres' roles and focuses on conserving coral reefs to support the tourism industry in Gili Trawangan.

Figure 6. Dive Centers' Roles and Focuses in Implementation of Coral Reef Conservation Programs

\begin{tabular}{|c|c|c|c|c|c|c|c|c|}
\hline \multirow[b]{2}{*}{ No } & \multirow[b]{2}{*}{$\begin{array}{l}\text { Coral Reef } \\
\text { Conservation } \\
\text { Programs }\end{array}$} & \multicolumn{5}{|c|}{ List of Dive Centers } & \multirow[b]{2}{*}{$\begin{array}{l}\text { Reasons for } \\
\text { Implementing } \\
\text { (V) Programs }\end{array}$} & \multirow[b]{2}{*}{$\begin{array}{l}\text { Reasons for Not } \\
\text { Implementing } \\
\text { (X) Programs }\end{array}$} \\
\hline & & $\begin{array}{c}\text { Blue } \\
\text { Marlin } \\
\text { Dive }\end{array}$ & Diversia & DSM & $\begin{array}{l}\text { Dream } \\
\text { Divers }\end{array}$ & $\begin{array}{c}\text { Blue } \\
\text { Marine } \\
\text { Dive }\end{array}$ & & \\
\hline 1. & Conservation event & $\mathrm{V}$ & $\mathrm{X}$ & $\mathrm{X}$ & $\mathrm{X}$ & $\mathrm{X}$ & $\begin{array}{l}\text { To motivate } \\
\text { conservation and to } \\
\text { raise awareness }\end{array}$ & $\begin{array}{l}\text { Does not suit } \\
\text { the focus of } \\
\text { dive centre }\end{array}$ \\
\hline 2. & $\begin{array}{l}\text { Education program } \\
\text { for students }\end{array}$ & $\mathrm{X}$ & $\mathrm{X}$ & $\mathrm{X}$ & $\mathrm{V}$ & $\mathrm{V}$ & $\begin{array}{l}\text { To provide education } \\
\text { regarding the } \\
\text { importance of } \\
\text { protecting reefs }\end{array}$ & $\begin{array}{l}\text { Does not suit } \\
\text { the focus of } \\
\text { dive centre }\end{array}$ \\
\hline 3. & Local staff training & $\mathrm{X}$ & $\mathrm{X}$ & $\mathrm{X}$ & $\mathrm{X}$ & $\mathrm{V}$ & $\begin{array}{l}\text { To provide information } \\
\text { and understanding of } \\
\text { coral reef conservation }\end{array}$ & $\begin{array}{l}\text { Does not suit } \\
\text { the focus of } \\
\text { dive centre } \\
\text { in conserving } \\
\text { coral reefs }\end{array}$ \\
\hline 4. & Dive against debris & V & $\mathrm{V}$ & $\mathrm{V}$ & $\mathrm{V}$ & $\mathrm{V}$ & $\begin{array}{l}\text { To raise awareness and } \\
\text { involvement in coral } \\
\text { reef conservation }\end{array}$ & - \\
\hline 5. & Biorock project & $\mathrm{V}$ & $\mathrm{X}$ & $\mathrm{X}$ & $\mathrm{X}$ & $\mathrm{X}$ & $\begin{array}{c}\text { To restore and } \\
\text { increase the growth } \\
\text { of coral reefs }\end{array}$ & Expensive cost \\
\hline 6. & No anchoring & $\mathrm{V}$ & $\mathrm{V}$ & $\mathrm{V}$ & $\mathrm{V}$ & $\mathrm{V}$ & $\begin{array}{l}\text { To behave as a } \\
\text { responsible tourism } \\
\text { business and prevent } \\
\text { coral breaking }\end{array}$ & - \\
\hline 7. & $\begin{array}{l}\text { Managing diver } \\
\text { behaviour }\end{array}$ & $\mathrm{V}$ & $\mathrm{V}$ & $\mathrm{V}$ & $\mathrm{V}$ & $\mathrm{V}$ & $\begin{array}{l}\text { To prevent coral from } \\
\text { breaking by divers }\end{array}$ & - \\
\hline 8. & $\begin{array}{l}\text { Limiting the } \\
\text { number of divers } \\
\text { in the dive group }\end{array}$ & V & V & V & $\mathrm{V}$ & $\mathrm{V}$ & $\begin{array}{l}\text { To reduce impacts } \\
\text { caused by scuba } \\
\text { diving activities }\end{array}$ & - \\
\hline 9. & $\begin{array}{l}\text { GET (Gili Eco } \\
\text { Trust) donation }\end{array}$ & $\mathrm{V}$ & $\mathrm{V}$ & V & $\mathrm{X}$ & $\mathrm{V}$ & $\begin{array}{l}\text { To provide a direct } \\
\text { financial contribution } \\
\text { to reef conservation }\end{array}$ & $\begin{array}{l}\text { Does not suit } \\
\text { the focus of } \\
\text { dive centre }\end{array}$ \\
\hline 10. & Beach clean-up & V & $\mathrm{V}$ & $\mathrm{V}$ & $\mathrm{X}$ & $\mathrm{V}$ & $\begin{array}{l}\text { To reduce impacts from } \\
\text { human activities and to } \\
\text { increase involvement }\end{array}$ & $\begin{array}{l}\text { Does not suit } \\
\text { the focus of } \\
\text { dive centre }\end{array}$ \\
\hline
\end{tabular}




\section{Conclusion}

This research revealed the five dive centres in Gili Trawangan - namely Marlin Dive, Diversia, DSM Dive, Dream Divers and Blue Marine Divehave a variety of roles in conserving coral reefs through conservation programs they implement. They have both differences and similarities in the programs they implement. It is discovered that ten conservation programs are being implemented by dive centres in Gili Trawangan comprising of conservation event, education program for kids, local staff training, dive against debris, bio rock project, no anchoring, managing diver behaviour, limiting number of divers in dive group, Gili Eco Trust (GET) donation, and beach clean-up. This research has further extended previous studies that have been conducted in the area, as it provides a deep understanding of roles of dive centre as one of the main stakeholders in the tourism and analyses their roles in conservation to support the tourism industry in Gili Trawangan.

The focuses of dive centres' roles in conserving coral reefs vary with one another. Blue Marlin Dive focuses on raising awareness and providing motivation for the public and tourists to be engaged in coral reef conservation. Diversia focuses on being a responsible business by implementing conservation programs with the capacity the dive centre has. DSM Dive focuses on being a responsible tourism business by implementing collaborative coral reef conservation programs. Dream Divers focuses its role on initiating individual coral reef conservation programs and providing education program. Blue Marine Dive focuses on using education as a tool for the conservation of coral reefs. Although the five dive centres have various focuses on implementing their roles, yet all dive centres share the common goal in conserving coral reefs, which is to support the tourism industry in Gili Trawangan.

\section{References}

Arin, T., \& Kramer, R. A. (2002). Divers' willingness to pay to visit marine sanctuaries: an exploratory study. Ocean \& Coastal Management, 45, 171183.

Astriani, H. (2018). Peta Administrasi Pulau Gili Trawangan. Yogyakarta.
Bachtiar, I. (2000). Community-Based Coral Reef Management of The Marine Tourism Park Gili Indah, Lombok Barat. Komunitas, 3(1), 67-77.

Balai Kawasan Konservasi Perairan Nasional Wilayah Kerja Taman Wisata Perairan Gili Matra. (2016). Taman Wisata Perairan Gili Ayer, GIli Meno dan Gili Trawangan. Nusa Tenggara Barat: BKKPN TWP Gili Matra.

Barker, \& Roberts. (2004). Scuba diver behaviour and the management of diving impacts on coral reefs. Biological Conservation, 120(4), 481-489.

Burke, e. a. (2002). Reefs at Risk in Southeast Asia. USA: Word Resources Institute.

Cesar, e. a. (2003). The Economics of Worldwide Coral Reefs Degradation. The Netherlands: Cesar Environmental Economics Consulting (CEEC).

Cesar, H. (1996). Economic Analysis of Indonesian Coral Reefs. Washington: The World Bank.

Charlie, Pearlman, \& King. (2013). A Conceptual Framework for Environmental Networks: an Analysis of Small Island Destinations in Indonesia and the Coral Triangle. WIT Transactions on Ecology and the Environment, 161, 189-202.

Clifton, J. (2004). Evaluating contrasting approaches to marine ecotourism:'Dive tourism' and 'Research tourism'in the Wakatobi Marine National Park, Indonesia. In Contesting the foreshore: tourism, society, and politics on the coast (pp. 151-168). Amsterdam: Amsterdam University Press.

Coral Reef Alliance. (2014). Why Care About Reefs? Retrieved April 19, 2017, from Coral Reef Alliance, USA: http://coral.org/coral-reefs-101/ why-care-about-reefs/tourism/

Dinas Kebudayaan dan Pariwisata Provinsi Nusa Tenggara Barat. (2016). Statistik Kebudayaan dan Pariwisata Provinsi Nusa Tenggara Barat 2016. Nusa Tenggara Barat: Dinas Kebudayaan dan Pariwisata Provinsi Nusa Tenggara Barat.

Dinas Pariwisata Kabupaten Lombok Utara. (2016). Data Gili Trawangan 2016. Pemenang: Dinas Pariwisata Kabupaten Lombok Utara.

Dinas Pariwisata Kabupaten Lombok Utara. (2016). Perkembangan Data Kunjungan Wisatawan Kab. Lombok Utara 2011-2016. Pemenang: Dinas Pariwisata Kabupaten Lombok Utara.

Edgell, D. L. (1990). International Tourism Policy. New York: Van Nostrand Reinhold.

Elliott, R., \& Timulak, L. (2005). Descriptive and Interpretive Approaches to Qualitative Research. In P. Gilbert, \& J. Miles, A Handbook of Research Methods for Clinical and Health Psychology (pp. 147-158). Oxford: Oxford University Press.

Environmental Protection Authority. (2016). Environmental Factor Guideline: Benthic 
Communities and Habitats. Western Australia: EPA.

Garrod, \& Gössling. (2008). Introduction. In Garrod, \& Gössling (Eds.), New Frontiers in Marine Tourism: Diving Experiences, Sustainability, Management (pp. 3-28). the Netherlands: Elsevier Ltd.

Goodall, B., \& Stabler, M. (2003). Tourism and sustainable community development. In D. Hall, \& G. Richards, Tourism and Sustainable Community Development (Vol. 7, p. 69). Psychology Press.

Goreau, T. J. (2009). Tourism and Sustainable Coral Reefs. USA: Global Coral Reef Alliance.

Gössling, e. a. (2008). Diving and Global Environmental Change: A Mauritius Case Study. In Garrod, \& Gossling (Eds.), New Frontiers in Marine Tourism: Diving Experiences, Sustainability, Management (pp. 67-92). The Netherlands: Elsevier Ltd.

Graci, \& Dodds. (2010). Sustainable Tourism in Island Destinations. Washington: Earthscan.

Hammersley, \& Atkinson. (2007). Ethnography: Principles in Practice. New York: Routledge.

Hariott, V. J. (2002). Marine tourism impacts and their management on the Great Barrier Reef. Townsville: CRC Reef Research Centre.

Hawkins, e. a. (2005). Sustainability of Scuba Diving Tourism on Coral Reefs of Saba. Coastal Management, 33(4), 373-387.

Hawkins, J. P., \& Roberts, C. M. (1992). Effects of recreational SCUBA diving on fore-reef slope of communities of coral reefs. Biological Conservation(62), 171-178.

Hilmi, e. a. (2012, September). Coral Reefs and Tourism in Egypt's Red Sea. Topics in Middle Eastern and African Economies, 14, 416-434.

Hsui, C., \& Wang, C. (2013). Synergy between fractal dimension and lacunarity index in design of artificial habitat for alternativr SCUBA diving site. Ecological engineering, 53, 6-14.

Kurniawan, e. a. (2016). Vulnerability assessment of small islands to tourism: The case of the Marine Tourism Park of Gili Matra Islands, Indonesia. Global Ecology \& Conservation, 6, 308-326.

Lindgrend, e. a. (2008). Environmental Management and Education: The Case of PADI. In Garrod, \& Gössling (Eds.), New Frontiers in Marine Tourism: Diving Experiences, Sustainability and Management (pp. 115-136). The Netherlands: Elsevier Ltd.

Mark, R. J. (The Economic Valuation of Coral Reefs: a Case Study of West Lombok, Indonesia). 2017. Halifax: Dalhousie University.
Menteri Kelautan dan Perikanan Republik Indonesia. (n.d.). Keputusan Menteri Kelautan dan Perikanan Nomor 57/KEPMEN-KP/2014 tentang Rencana Pengelolaan dan Zonasi Taman Wisata Perairan Pulai Gili Ayer, Gili Meno dan Gili Trawangan di Provinsi Nusa Tenggara Barat Tahun 2014 - 2034.

Milles, M., \& Huberman, A. (1994). Qualitative Data Analysisi: An Expanded Sourcebook (2nd ed.). California: Sage.

Poonian, e. a. (2010). Impacts of Recreational Divers on Palauan Coral Reefs and Options for Management. Pasific Science, 64(4), 557-565.

Ray, G. C., \& Ray, J. M. (2004). Coastal-Marine Conservation: Science and Policy. USA: Blackwell Publishing.

Razak, e. a. (2014). Tourism Sea Activities that Cause Damages Towards Coral Reefs in Sembilan Islands. Tourism, Leisure and Global Change, 1, 123-134.

Rianto, A. B. (2014). Institutional Challenges in Managing Marine Protected Areas: The Case of TWP Gili Matra, West Nusa Tenggara, Indonesia. Japan: Tohoku University.

Richards, \& Hall. (2000). Tourism and Sustainable Community Development. London: Routledge.

Stanford, P. J., \& Seymour, D. (2007). A discussion of qualitative data analysis in hospitality research with examples from an ethnography of English public houses. Hospitality Management, 26, 724742.

Suana, I. W., \& Ahyadi, H. (2012, October). Mapping of Ecosystem Management Problem in Gili Meno, Gili Air and Gili Trawngan (Gili Matra) through Participative Approach. Journal of Coastal Development, 16, 94-101.

Swarbrooke, J. (1999). Sustainable Tourism Management. London: $\mathrm{CAB}$ International.

Taylor, S. J., Bogdan, R., \& DeVault, M. L. (2016). Introduction to qualitative research methods: a guidebook and resource (4th ed.). John Wiley and Sons, Inc.

Tinumbia, e. a. (2016). Penerapan Prinsip Ekowisata pada Perancangan Fasilitas Pengelolaan Ekosistem Terumbu Karang di Gili Trawangan. Jurnal Mahasiswa Jurusan Arsitektur, 4(1).

Townsend, C. (2008). Dive Tourism, Sustainable Tourism and Social Responsibility: A Growing Agenda. In Garrod, \& Gössling (Eds.), New Frontiers in Marine Tourism: Diving Experiences, Sustainability and Management (pp. 139-152). The Netherlands: Elsevier Ltd.

Treeck, \& Eisinger. (2008). Diverting Pressure from Coral Reefs: Artificial Underwater Parks as a Means of Intergrating Development and Reef 
Conservation. In Garrod, \& Gössling (Eds.), New Frontiers in Marine Tourism: Diving Experiences, Sustainability and Management (pp. 153-169). The Netherlands: Elsevier Ltd.

United Nations Environment. (2017). Tourism and Environmental Conservation | Resource Effeciency. Retrieved September 30, 2017, from unep.org: http://drustage.unep.org/ resourceefficiency/tourism-and-environmentalconservation

United States Coral Reef Task Force. (2000). The National Action Plan to Conserve Coral Reefs. Washington, D.C.: United States Coral Reef Task Force.

Whitehead, T. L. (2005). Cultural Ecology of Health and Change: Ethnographically Informed Community and Cultural Assessment Research Systems Working Paper Series. USA: University of Maryland.

Wongthong, P., \& Harvey, N. (2014). Integrated coastal management and sustainable tourism: A case study of the reef based SCUBA dive industry from Thailand. Ocean \& Coastal Management, 95, 138-146.

World Conservation Union's World Commission on Protected Areas. (2003). Recommendations of the Vth IUCN World Parks Congress. Washington DC: IUCN.

World Wildlife Fund. (2016). Coral Triangle. Retrieved February 23, 2017, from World Wildlife Fund: http://www.worldwildlife.org/places/coraltriangle 